\title{
Biaya Modal Perusahaan di Indonesia: Tanggung Jawab Sosial dan Tata Kelola Perusahaan
}

\author{
Amrie Firmansyah ${ }^{1)}$, Arifah Fibri Andriani' ${ }^{2)}$, Moch. Luthfi Mahrus ${ }^{3)}$, Wahyudi \\ Febrian $^{4)}$, Pramuji Handar Jadi ${ }^{5}$ ) \\ 1,4,5Program D4 Akuntansi Sektor Publik, Politeknik Keuangan Negara STAN \\ ${ }^{2,3}$ Program D3 Akuntansi, Politeknik Keuangan Negara STAN
}

\author{
Email Address: \\ amrie@pknstan.ac.id
}

\begin{abstract}
The high capital cost indicates the company's risk to obtain funding from debt and equity. The test in this study aims to prove the association between corporate social responsibility and corporate governance with the cost of capital. This study employs data sourced from financial reports and annual reports of the listed companies on the Indonesia Stock Exchange, downloaded from www.idx.co.id. In addition, this research data also employs stock price information sourced from finance.yahoo.com. The sample selection in this study used purposive sampling with a total sample of 260 observations from 65 companies from 2016 to 2019. The hypothesis test in this study used multiple linear regression analysis for panel data. This study concludes that corporate governance is positively associated with the cost of capital, while corporate social responsibility is negatively associated with the cost of capital. This study suggests that Indonesia's capital market supervisory authority needs to improve its governance policies and governance oversight mechanisms for companies listed on the Indonesia Stock Exchange.
\end{abstract}

Keywords: corporate risk, transparency, sustainability.

\begin{abstract}
Abstrak: Biaya modal yang tinggi menunjukkan risiko yang harus ditanggung oleh perusahaan dalam rangka untuk mendapatkan pendanaaan baik yang bersumber dari utang maupun dari ekuitas. Pengujian dalam penelitian ini bertujuan untuk membuktikan pengaruh tanggung jawab sosial perusahaan dan tata kelola perusahaan terhadap biaya modal. Penelitian ini menggunakan data berupa informasi yang bersumber laporan keuangan dan laporan tahunan yang terdaftar di Bursa Efek Indonesia yang diunduh dari www.idx.co.id. Selain itu, data penelitian ini juga menggunakan informasi harga saham yang bersumber dari finance.yahoo.com. Pemilihan sampel dalam penelitian ini menggunakan purposive sampling dengan total sampel berjumlah 260 observasi yang berasal dari 65 perusahaan selama tahun 2016 sampai tahun 2019. Uji hipotesis dalam penelitian ini menggunakan uji analisis regresi linier berganda untuk data panel. Penelitian ini menunjukkan bahwa tata kelola perusahaan berpengaruh positif terhadap biaya modal, sedangkan tanggung jawab sosial perusahaan berpengaruh negatif terhadap biaya modal. Penelitian ini menunjukkan bahwa otoritas pengawas pasar modal di Indonesia perlu memperbaiki kebijakan tata kelola dan mekanisme pengawasan tata kelola atas perusahaan listed di Bursa Efek Indonesia.
\end{abstract}

Kata Kunci: risiko perusahaan, transparansi, keberlanjutan. 


\section{PENDAHULUAN}

Dalam menjalankan bisnis operasinya, perusahaan membutuhkan pendanaan yang bersumber dari utang dan saham (Ida, 2010). Di satu sisi, pendanaan perusahaan yang bersumber dari utang dapat meningkatkan kinerja perusahaan (Salman et al, 2020), karena manajer dapat bekerja lebih optimal untuk memenuhi kewajiban atas utang yang ditanggung perusahaan. Di sisi lain, penggunaan utang dapat meningkatkan risiko keuangan berupa kesulitan keuangan (Parendra et al., 2020). Kreditor memiliki hak untuk mengajukan klaim kepailitan apabila perusahaan tidak mampu memenuhi kewajibannya yang telah jatuh tempo (Shleifer dan Visny, 1997; Hidayah dan Firmansyah, 2020). Oleh karena itu, manajer perlu menyeimbangkan penggunaan utang dan ekuitas pada titik optimal agar terhindar dari resiko gagal bayar dan manfaat penggunaan utang dapat diperoleh perusahaan.

Pendanaan erat kaitanya dengan resiko yang ditanggung oleh perusahaan karena setiap penggunaan dana membutuhkan biaya yang harus ditanggung oleh perusahaan (Fahira et al., 2020; Febrininta dan Siregar, 2014). Sementara itu, investor dan kreditor mengharapkan tingkat pengembalian yang tinggi atas dana yang telah diberikan kepada perusahaan (Shleifer dan Vishny, 1997). Dari sudut pandang perusahaan, tingkat pengembalian tersebut merupakan biaya modal yang harus ditanggung oleh perusahaan. Perusahaan akan lebih mudah untuk mendapatkan pendanaan apabila dapat meningkatkan biaya modal karena kompensasi pemilik modal mengharapkan tingkat pengembalian yang tinggi (Firmansyah et al., 2020), ataupun persyaratan kredit yang lebih longgar untuk biaya utang yang tinggi (Firmansyah et al., 2020).

Biaya modal yang tinggi berkorelasi dengan risiko keuangan dari penggunaan utang dan ekuitas dalam struktur permodalannya. Perusahaan yang terlibat dalam kebijakan yang berisiko menimbulkan tuntutan lebih dari investor dan kreditor berupa peningkatkan pengembalian yang diharapkan. Perusahaan akan menetapkan biaya modal yang lebih tinggi melalui peningkatan biaya bunga, dividen dan penurunan harga saham melebihi tingkat pengembalian yang diharapkan (Febrininta dan Siregar, 2014). Biaya modal yang tinggi mendorong investor dan kreditor untuk menempatkan dananya kepada perusahaan karena investor dan kreditor dapat memperoleh tingkat pengembalian yang tinggi. Di sisi lain, biaya modal menjadi faktor penentu pendanaan dalam struktur pendanaan yang optimal demi meningkatkan nilai perusahaan (Febrininta dan Siregar, 2014). Hakikatnya, perusahaan mendapatkan biaya modal yang rendah untuk mengurangi dampak biaya-biaya yang dikeluarkan perusahaan kepada invetor dan kreditor. Biaya modal yang rendah juga menunjukkan risiko yang rendah karena pemilik dana baik investor dan kreditor mempercayai reputasi perusahaan yang telah dibangun (Shleifer dan Vishny, 1997).

Terkait dengan pilihan penggunaan sumber dana dalam struktur modal perusahaan, perusahaan lebih menggunakan utang untuk mendapatkan biaya modal yang lebih rendah karena adanya pengaruh pajak biaya utang lebih rendah daripada biaya ekuitas (Brigham dan Houston, 2018). Namun manfaat dari peningkatan rasio utang tidak selamanya mengguntungkan perusahaan (Brigham dan Houston, 2018) karena penggunaan utang lebih besar dibandingkan dengan ekuitas akan meningkatkan risiko gagal bayar (Salman et al., 2020, Firmansyah et al., 2020). Selain itu, penggunaan utang akan meningkatkan akses informasi kepada kreditur dalam menetapkan keputusan investasi yang diambil oleh manajer yang memicu adanya asimetri informasi antara kreditur dan pemegang saham biasa. 
Pemegang saham biasa yang memiliki akses informasi lebih sedikit akan meningkatkan tingkat pengembalian yang diharapkan sehingga biaya ekuitas menjadi meningkat. Tingkat pengembalian yang lebih tinggi ini mencerminkan risiko yang ditanggung oleh pemegang saham biasa karena pemegang saham biasa tidak mendapatkan informasi yang lebih baik dibandingkan dengan kreditor (Yeh et al., 2019). Sementara itu, biaya modal yang lebih rendah tidak hanya memberikan peluang bagi perusahaan untuk mengumpulkan dana yang diperlukan untuk ekspansi bisnis, tetapi juga dapat meningkatkan kinerja perusahaan (Appuhami, 2018). Perusahaan dapat mencapai biaya modal yang lebih rendah dengan meminimalkan asimetri informasi antara manajer dan penyedia modal (Jensen dan Meckling, 1976). Pengurangan asimetri informasi bermanfaat bagi perusahaan karena memungkinkan penyedia modal untuk menilai risiko yang terkait untuk setiap perusahaan dan menentukan tingkat pengembalian yang diharapkan atas peluang investasi (Appuhami, 2018).

Biaya modal yang tinggi dapat melonggarkan persyaratakan pendanaan dari utang dan ekuitas, namun hal tersebut dapat mendorong risiko perusahaan yang semakin tinggi. Manajer akan lebih mudah untuk mendapatkan dana sesuai dengan motif yang dijalankan dengan meningkatkan biaya modal perusahaan. Pelonggaran persyaratan dalam memperoleh sumber pendanaan eksternal dapat meningkatkan informasi asimetri antara manajer dengan investor dan kreditor. Manajer memiliki diskresi dalam penggunaan sumber dana sesuai dengan tujuan tertentu yang hendak dicapai. Kondisi ini sejalan dengan ekspektasi investor dan kreditor atas tingkat pengembalian yang tinggi. Sumber pendanaan eksternal yang lebih mudah diperoleh akan melonggarkan persyaratan dari perusahaan kepada pemilik dana eksternal. Namun, tingkat biaya modal yang tinggi memberikan konsekuensi kepada perusahaan untuk memiliki kewaijban yang lebih tinggi dalam bentuk tingkat pengembalian kepada pemilik dana. Kondisi tersebut dapat menurunkan kinerja perusahaan. Oleh karena itu, pengujian atas biaya modal perlu untuk diinvestigasi lebih lanjut.

Pengujian biaya modal dalam penelitian sebelumnya dilakukan secara parsial dengan biaya utang yang dilakukan oleh (Firmansyah et al., 2020) dengan menggunakan kebijakan dividen, volatilitas laba, dan kualitas akrual. (Kovermann, 2018) menguji penghindaran pajak dan risiko pajak terhadap biaya utang. (Le et al., 2021) menguji kualitas akrual terhadap biaya utang. (Yeh et al., 2019) menguji tanggung jawab sosial terhadap biaya ekuitas dan biaya utang. (Matthiesen dan Salzmann, 2016), (Weber, 2018), (Chen dan Zhang, 2021) menguji tanggung jawab sosial terhadap biaya ekuitas. (Raimo et al., 2021) menguji pengungkapan environmental, social and governance (ESG). Appuhami (2018) menguji karakteristik komite audit terhadap biaya modal ekuitas. (Teti et al., 2016) menguji tata kelola perusahaan terhadap biaya ekuitas. Faysal (2020) menguji struktur kepemilikan terhadap biaya ekuitas.Sementara itu, (Febriyanto dan Firmansyah, 2018) menguji biaya ekuitas dengan menggunakan penghindaran pajak, manajemen laba dan intensitas modal. (Anggraeni dan Indarti, 2021), (Huagol dan Lubis, 2021) dan (Erbach, 2020) menguji modal intelektual terhadap biaya ekuitas. (Rohman dan Ismanto, 2020) dan (Widyowati, 2021) menguji manajemen laba dan terhadap biaya ekuitas. (Arimbi dan Indarti, 2021) menguji tata kelola perusahaan terhadap biaya modal ekuitas.

Dalam perspektif pemangku kepentingan, perusahaan dituntut untuk lebih transparan dalam mengungkapkan informasi yang relevan kepada publik (Firmansyah dan 
Estutik, 2020). Penerapan tata kelola perusahaan yang baik dan tanggung jawab sosial yang tinggi merupakan salah satu tuntutan dari pemangku kepentingan bagi perusahaan untuk memberikan informasi yang lebih transparan. Pemangku kepentingan memiliki peran dalam pengawasan secara tidak langsung dalam meningkatkan kinerja perusahaan. Perusahaan akan lebih berhati-hati dalam mengambil kebijakan yang memiliki dampak risiko yang berbahaya bagi keberlangsungan perusahaan di masa depan. Tingkat biaya modal yang tinggi relevan dengan tingkat risiko yang tinggi akibat persyaratan pendanaan yang lebih longgar, khususnya dari kreditor. Selain itu, pengungkapan tata kelola perusahaan dan tanggung jawab sosial perusahaan menjadi semakin penting dalam membangun reputasi perusahaan, keunggulan kompetitif, dan pengambilan keputusan investasi (Tamimi dan Sebastianelli, 2017). (Eccles et al., 2011) menyimpulkan bahwa banyak investor menganggap pengungkapan tata kelola perusahaan dan tanggung jawab sosial preusahaan sebagai proksi untuk penilaian kualitas manajemen. Selanjutnya, pengungkapan tata kelola perusahaan dan tanggung jawab sosial mendukung penilaian investor terhadap peluang, risiko, transparansi, dan kinerja masa depan perusahaan (Albarrak et al., 2019).

Tanggung jawab sosial perusahaan telah menjadi perhatian manajemen yang penting di perusahaan secara global dan telah diterapkan secara luas di negara berkembang (Vermander, 2014). (Jo dan Harjoto, 2015) membuktikan bahwa tanggung jawab sosial perusahaan dapat mengurangi asimetri informasi, risiko pasar, dan biaya transaksi, yang mencerminkan biaya modal ekuitas. Selain itu, (Girerd-Potin et al., 2014) menemukan bahwa investor memerlukan kompensasi risiko tambahan ketika berinvestasi di perusahaan dengan kinerja tanggung jawab sosial yang buruk. (Xu et al., 2015) menyimpulkan bahwa tanggung jawab sosial yang dijalankan perusahaan dapat mengurangi biaya modal ekuitas. (Chang et al., 2014) menegaskan bahwa kegiatan tanggung jawab sosial perusahaan dapat mengurangi biaya pendanaan kredit bank dan pasar ekuitas. Namun, pengujian yang dilakukan oleh (Botosan dan Plumlee, 2011), dan (Taylor dan Verrecchia, 2015) menemukan bahwa kinerja tanggung jawab sosial mempengaruhi secara positif biaya ekuitas. Hasil pengujian tersebut menunjukkan terdapat adanya inkonsistensi pengujian tanggung jawab sosial perusahaan terhadap biaya ekuitas, yang merupakan bagian dari biaya modal.

Standar tata kelola yang baik dapat mengurangi masalah keagenan dengan membatasi perilaku oportunistik manajer, memantau tindakan manajer dan meningkatkan kualitas arus informasi perusahaan (Teti et al., 2016). Namun, perlindungan investor dalam penerapan tata kelola tingkat perusahaan masih belum jelas (Hail dan Leuz, 2006). Tata kelola yang efektif juga dapat mengurangi risiko, sehingga dapat menurunkan biaya modal (Chen et al., 2009). (Brown dan Caylor, 2006) menemukan bahwa tata kelola perusahaan dapat meningkatkan kinerja perusahaan. (Dittmar dan Mahrt-Smith, 2007) dan (Masulis et al., 2007) menyimpulkan bahwa tata kelola yang tidak efektif mengakibatkan penurunan nilai pemegang saham, sebagai akibat dari praktik penganggaran modal yang salah oleh manajer, atau karena devaluasi sumber daya kas. Sementara itu, (Firmansyah et al., 2021) menemukan bahwa penerapan tata kelola perusahaan menurunkan nilai perusahaan, namun tidak memiliki peran dalam menurunkan hubungan manajemen laba dan risiko idiosinkratik (Firmansyah dan Suhanda, 2021).

Penelitian ini bertujuan untuk menguji tanggung jawab sosial perusahaan dan tata kelola perusahaan terhadap biaya modal. (Yeh et al., 2019) hanya menguji tanggung jawab 
sosial perusahaan terhadap biaya ekuitas dan biaya utang secara terpisah, bukan dalam konteks terhadap biaya modal secara keseluruhan. (Matthiesen dan Salzmann, 2016), (Weber, 2018), (Chen dan Zhang, 2021) hanya menguji tanggung jawab sosial terhadap biaya ekuitas. Raimo et al. (2021) menguji pengungkapan environmental, social and governance (ESG). Sementara itu, penelitian ini menguji biaya modal dengan menggabungkan biaya utang dan biaya ekuitas dengan tanggung jawab sosial perusahaan dan tata kelola perusahaan, sehingga penelitian ini dapat melengkapi penelitian-penelitian sebelumnya dengan topik pengujian yang sejenis.

Penelitian ini memiliki kontribusi dalam perkembangan riset akuntansi keuangan berbasis pasar modal khususnya dengan menggunakan data Indonesia sehingga dapat melengkapi terkait dengan biaya modal yang diuji dengan tanggung jawab sosial dan tata kelola perusahaan. Selain itu, penelitian ini dapat digunakan oleh Otoritas Jasa Keuangan selalu institusi yang mengawasi pasar modal di Indonesia dalam mengembangkan kebijakan tata kelola dan tanggung jawab sosial perusahaan yang berlaku untuk emiten di Indonesia.

\section{KAJIAN TEORI}

Manajer dapat menggunakan diskresinya dalam menjalankan bisnis operasi perusahaan, termasuk menggunakan data yang tersedia dalam perusahaan. Manajer memiliki informasi yang lebih sempurna akan sumber daya perusahaan (Firmansyah et al., 2021). Keunggulan manajer dalam menjalankan bisnis perusahaan dapat mengakibatkan penggunaan dana yang tersedia dalam perusahaan sesuai dengan motif yang diinginkan oleh manajer tersebut. Di sisi lain, teori pemangku kepentingan menuntut manajer untuk berperilaku etis dalam menjalankan bisnis perusahaan (Firmansyah dan Estutik, 2020). Salah satu upaya perusahaan dalam memenuhi kepentingan berbagai pemangku kepentingan adalah dengan menjalankan tanggung jawab sosial perusahaan. (Albuquerque et al., 2013) menyimpulkan bahwa investasi yang dikeluarkan oleh perusahaan untuk menjalankan aktivitas tanggung jawab sosial bertujuan untuk mengurangi risiko sistemik dan meningkatkan nilai perusahaan dengan memperluas diferensiasi produk. Sejalan dengan hal tersebut, (Bouslah et al., 2013), dan (Chollet dan Sandwidi, 2018) menegaskan peran tanggung jawab sosial perusahaan dalam mengurangi risiko idiosinkratik dan sistemik. Aktivitas tanggung jawab sosial perusahaan dapat meningkatkan kemampuan penetapan harga produk dengan meningkatkan kepuasan dan loyalitas pelanggan dan mengurangi risiko fluktuasi pendapatan (Ailawadi et al., 2014; Galbreath dan Shum, 2012). Selain itu, tanggung jawab sosial perusahaan juga dapat mengurangi risiko reputasi melalui menurunkan asimetri informasi publik dan menciptakan opini publik yang menguntungkan (Cui et al., 2018) dan menghindari risiko litigasi yang disebabkan oleh pelanggaran hak karyawan (Flammer dan Luo, 2017). Penerapan tanggung jawab sosial perusahaan juga dapat meningkatkan kepercayaan pemasok, sehingga meningkatkan stabilitas dalam rantai pasokan dan memperbaiki kondisi operasi (Yawar dan Seuring, 2017; Zhang et al., 2014). (El Ghoul et al., 2011) menyimpulkan bahwa perusahaan dengan kinerja tanggung jawab sosial perusahaan yang buruk memiliki persepsi risiko yang lebih tinggi, sehingga investor mencari kompensasi terkait dengan hal tersebut. Selanjutnya, (Matthiesen dan Salzmann, 2016), (Weber, 2018), (Chen dan Zhang, 2021) membuktikan bahwa penerapan tanggung jawab sosial perusahaan dapat menurunkan biaya ekuitas. 
Walaupun perusahaan memperoleh kelonggaran persyaratan dengan memperoleh sumber pendanaan baik dari utang dan saham, namun kemudahan tersebut relevan dengan risiko yang harus ditanggung oleh perusahaan karena perusahaan akan menanggung biaya modal perusahaan yang semakin tinggi. Terkait dengan hal tersebut, penerapan tanggung jawab sosial perusahaan dapat mendorong manajer untuk memperhatikan kepentingan pemangku kepentingan, sehingga manajer akan lebih berhati-hati dalam mengambil kebijakan yang mempengaruhi bisnis perusahaan. Selain itu, penerapan tanggung jawab sosial dapat mendorong perusahaan lebih transparan dalam mengungkapkan informasi kepada pemangku kepentingan.

H1: Tanggung jawab sosial berpengaruh negatif terhadap biaya modal.

Teori keagenan menyatakan bahwa adanya konflik antara pemegang saham dan manajer di dalam perusahaan karena terdapat perbedaan kepentingan keduanya. Pemegang saham dapat mengurangi divergensi dengan menetapkan insentif yang sesuai untuk agen, dan dengan mendukung biaya pengawasan yang bertujuan untuk membatasi tindakan oportunistik yang dilakukan oleh agen (Hill dan Jones, 1992). Pemegang saham dapat membayar agen dan menanggung tambahan biaya keagenan untuk untuk memastikan bahwa agen tidak akan mengambil tindakan yang dapat merugikan kepentingan pemegang saham, namun konflik antara keduanya tetap tetap terjadi (Teti et al., 2016).

Adanya permasalahan antara manajer dan pemegang saham tersebut dapat diturunkan dengan menerapkan tata kelola yang efektif (Teti et., 2016). Penerapan tata kelola yang baik mampu untuk mengurangi konflik tersebut sehingga perusahaan dapat meningkatkan nilai perusahaan dan mengurangi biaya ekuitas (La Porta et al., 2000). Bahkan, pemegang saham akan bersedia untuk memiliki harapan yang lebih rendah terkait dengan tingkat pengembalian pada perusahaan-perusahaan yang telah menerapkan tata kelola, sehingga kondisi ini mampu mengurangi biaya agensi dan hak-hak pemegang saham itu sendiri lebih terlindungi (Mehdi, 2007; Garay dan Gonzales, 2008). Tata kelola perusahaan dapat berperan dapat mengurangi biaya agensi dan selanjutnya dapat mengurangi biaya modal. Tata kelola perusahaan dapat mengurangi risiko pengambilalihan oleh manajer, yang tidak hanya bergantung pada faktor spesifik perusahaan tetapi juga pada variabel pasar (Durnev dan Kim, 2005). Dalam periode negatif, risiko pasar dapat meningkat, ketika tanpa praktik tata kelola yang tepat, dapat meningkatkan pengembalian ekuitas yang lebih tinggi, seperti yang dipersyaratkan oleh pemegang saham yang menanggung risiko lebih tinggi. Tata kelola perusahaan dapat melindungi dari biaya agensi dengan mengurangi biaya pemantauan yang biasanya dilakukan oleh investor eksternal. Persyaratan pemantauan yang lebih rendah dapat diubah menjadi expected return yang lebih rendah dari pemegang saham, sehingga kondisi tersebut mendukung risiko yang lebih rendah (Lombardo dan Pagano, 2002). Selanjutnya, tata kelola perusahaan yang efektif dapat berguna untuk membatasi asimetri informasi dengan menurunkan insider trading, sedangkan penerapan tata kelola yang lemah seperti dalam perusahaan keluarga, insider trading menjadi tinggi (Crespi dan Martin-Oliver, 2015; Hung dan Trezevant, 2003).

(Morey et al., 2009) menyimpulkan bahwa peningkatan tata kelola menghasilkan penilaian perusahaan yang jauh lebih tinggi. Biaya ekuitas yang merupakan bagian dari biaya modal memiliki keuntungan di mana tingkat pengembalian yang diharapkan investor 
didasarkan pada risiko operasi perusahaan saat ini (Drobetz et al., 2004; Botosan dan Plumlee, 2002). Selain itu, biaya ekuitas bereaksi dengan cara yang lebih akurat terhadap perubahan tata kelola perusahaan secara tahunan dan tidak dipengaruhi oleh faktor eksogen, yang malah memengaruhi profitabilitas dan pertumbuhan di masa depan (Hail dan Leuz, 2006). (Dittmar dan Mahrt-Smith, 2007) dan (Masulis et al., 2007) menyimpulkan bahwa standar tata kelola yang tidak efektif mengakibatkan penurunan nilai pemegang saham, sebagai akibat dari praktik penganggaran modal yang salah oleh manajer, atau karena devaluasi sumber daya kas. Sementara itu, (Brown dan Caylor, 2006) menemukan bahwa kinerja perusahaan berpengaruh positif terhadap tata kelola perusahaan. (Schauten et al., 2008) menyimpulkan bahwa tata kelola secara positif terkait dengan nilai kas yang berlebih. (Lei dan Song, 2005) menunjukkan bahwa peringkat indeks tata kelola yang lebih baik dikaitkan dengan nilai perusahaan yang lebih tinggi.

Penerapan tata kelola yang baik dapat menurunkan biaya modal karena dapat menurunkan informasi asimetri. Adanya tuntuntan para pemangku kepentingan mengakibatkan manajemen berusaha untuk lebih transparan dalam mengungkapkan informasi yang dibutuhkan oleh berbagai pihak, termasuk kreditor dan investor. Investor dan kreditor akan memberikan dananya kepada perusahaan yang telah menerapakan tata kelola perusahaan yang baik. Walaupun tanpa jaminan resmi, perusahaan yang telah menerapkan tata kelola perusahaan yang baik mempunyai reputasi yang baik dalam menjalankan aktivitas bisnisnya.

H2: Tata kelola perusahaan berpengaruh negatif terhadap biaya modal perusahaan.

\section{METODOLOGI}

Penelitian ini menggunakan data sekunder yang meliputi data laporan keuangan perusahaan manufaktur yang terdaftar di Bursa Efek Indonesia dalam kurun waktu 2012 sampai 2019 diperoleh dari www.idx.co.id. Data lainnya terdiri dari informasi harga saham yang bersumber dari finance.yahoo.com. Penelitian ini menggunakan perusahaan manufaktur dipilih karena memiliki struktur keuangan yang mencerminkan struktur modal secara umum dan meliputi perusahaan terbanyak dibandingkan dengan sektor lainnya. Data penelitian dimulai tahun 2016 karena tahun tersebut merupakan tahun efektif penerapan Pedoman Tata Kelola Perusahaan sebagaimana Surat Edaran Otoritas Jasa Keuangan Nomor 32 tahun 2015.

Adapun sampel penelitian dengan purposive sampling adalah sebagai berikut:

Tabel 1. Sampel Penelitian

\begin{tabular}{lcc}
\hline Kriteria & Jumlah & Keterangan \\
\hline Emiten yang terdaftar di BEI per Juni 2021 & 739 & Perusahaan \\
Emiten yang terdaftar di BEI setelah 1 Januari 2016 & -297 & Perusahaan \\
Emiten di luar sektor manufaktur & -303 & Perusahaan \\
Emiten dengan data tidak lengkap & -74 & Perusahaan \\
Jumlah emiten yang dapat digunakan sebagai sampel & 65 & Perusahaan \\
Jumlah tahun yang digunakan dalam penelitian (2016-2019) & 4 & Tahun \\
Total Sampel & 260 & Observasi \\
\hline
\end{tabular}


Biaya modal merupakan variabel dependen dalam penelitian ini, diukur dengan WACC (Weighted Avarage Cost of Capital). Nilai WACC yang tinggi dianggap kurang baik bagi perusahaan (Damilano et al., 2018). Pengukuran WACC penelitian ini menggunakan proksi mengikuti (Battisti et al., 2020) yaitu:

$$
\mathrm{COC}=\mathrm{WACC}=\mathrm{COE} * \mathrm{WE}+\mathrm{COD} * \mathrm{WD}
$$

Di mana:

COE : biaya ekuitas

COD : biaya utang (setelah pajak)

WE dan WD : rata-rata tertimbang dari masing-masing komponen pada struktur modal

Untuk mengukur biaya modal, penelitian ini menggunakan excess returns yang diterima oleh investor sebagaimana (Francis et al., 2005) dan (Ben-Nasr et al., 2012) yaitu:

Di mana :

$$
\text { COEit }=\text { Rit }-\mathrm{Rft}=\alpha+\beta(\mathrm{Rmt}-\mathrm{Rft})
$$

$\mathrm{R}_{\text {it }}$

Rft

$\mathrm{Rmt}$

$\beta$

: tingkat pengembalian perusahaan i periode $\mathrm{t}$

tingkat pengembalian bebas risiko periode $\mathrm{t}$ dengan menggunakan yield obligasi pemerintah Indonesia 10 tahunan

: systemtic risk

Proksi biaya utang dalam penelitian ini mengikuti Francis et al. (2005) dengan menghitung rasio dari beban bunga pada suatu periode dibagi dengan interest bearing debt outstanding dengan persamaan sebagai berikut.

$$
\text { CODit }=\frac{\text { interest }}{\text { interest bearing debt outstanding }}
$$

Variabel independen dalm penelitian ini terdiri dari pengungkapan tanggung jawab sosial dan tata kelola perusahaan. Proksi tanggung jawab sosial dalam penelitian ini menggunakan indeks Global Reporting Initiative (GRI) sebagaimana (Lee et al., 2015) dan (Firmansyah dan Estutik, 2020). Indeks GRI dibangun dengan menggunakan sistem checklist dan pembobotan yang mengikuti standard GRI yang sudah disesuaikan. Checklist yang digunakan memiliki 91 indikator yang terbagi menjadi kategori ekonomi yang memiliki 9 indikator, kategori lingkungan yang memiliki 34 indikator, dan kategori sosial yang terdiri dari praktik ketenagakerjaan dan kenyamanan berjumlah 16 indikator, hak asasi manusia berjumlah 12 indikator, masyarakat berjumlah 11 indikator, dan tanggung jawab atas produk sebanyak 9 indikator. Nilai 0 diberikan untuk item yang tidak diungkapkan, nilai 1 untuk pengungkapan item minimum atau disebutkan secara singkat, nilai 2 untuk item yang menyajikan item secara deskriptif dengan menyampaikan informasi terkait dengan dampak bagi perusahaan atau kebijakan yang jelas, nilai 3 untuk penyajian item secara deskriptif dan kuantitatif dengan menyampaikan informasi dampak bagi perusahaan secara jelas didefinisikan dalam istilah moneter atau kuantitas fisik, nilai 4 untuk penyajian item yang dijelaskan telah memenuhi seluruh ketentuan dalam standar. 
Formula indeks pengungkapan tanggung jawab sosial dihitung dengan:

Dimana :

$$
\text { CSRIit }=\frac{\sum \mathrm{Xit}}{\mathrm{n}}
$$

$\mathrm{CSRI}_{\text {it }} \quad$ : Indeks tanggung jawab sosial perusahaan i pada tahun $\mathrm{t}$

$\mathrm{X}_{\mathrm{it}}$

: Nilai total pengungkapan tanggung jawab sosial perusahaan i pada tahun $\mathrm{t}$

$\mathrm{n}$

: Jumlah nilai maksimum pengungkapan tanggung jawab sosial

Tata kelola perusahaan dalam penelitian menggunakan indeks yang dikembangkan dari Surat Edaran Otoritas Jasa Keuangan Nomor 32 tahun 2015, sebagaimana (Firmansyah et al., 2021), (Damayanti dan Firmansyah, 2021) dan (Putri et al., 2020). Skor 1 jika perusahaan mengungkapan informasi sebagaimana aturan tersebut, nilai 0 jika sebaliknya.

$$
\text { CGit }=\frac{\text { skor standar tata kelola perusahaan terpenuhi }}{\text { total kriteria dalam checklist tata kelola perusahaan }}
$$

Penelitian ini juga menggunakan lima variabel kontrol yang terdiri dari leverage, market-to-book, profitabilitas, ukuran perusahaan, dan kebijakan utang. Leverage merupakan rasio dari total utang dibagi total aset sebagaimana proksi yang digunakan oleh (Yeh et al., 2019), (Kovermann, 2018), (Teti et al., 2016).

$$
\text { LEVit }=\frac{\text { Total utang perusahaan } \text { i pada periode } \mathrm{t}}{\text { Total ekuitas perusahaan i pada periode } \mathrm{t}}
$$

Market-to-book diukur dengan menggunakan rasio nilai kapitalisasi pasar dibagi nilai buku ekuitas sebagaimana proksi yang digunakan oleh (Yeh et al., 2019), (Kovermann, 2018), (Teti et al., 2016).

$$
\text { MTBit }=\frac{\text { Nilai kapitalisasi pasar perusahaan i pada periode } t}{\text { Nilai buku ekuitas perusahaan i pada periode } t}
$$

Profitabilitas menunjukkan kemampuan perusahaan memanfaatkan total aset yang dimilikinya yang dapat diukur dengan Return on Assets (ROA) sebagaimana proksi yang digunakan oleh (Yeh et al., 2019), (Kovermann, 2018), (Teti et al., 2016).

$$
\text { ROAit }=\frac{\text { Laba rugi perusahaan } \text { i pada periode } \mathrm{t}}{\text { Total aset perusahaan i pada periode } \mathrm{t}}
$$

Ukuran perusahaan pada penelitian menggunakan proksi yang digunakan (Yeh et al., 2019), (Kovermann, 2018), (Teti et al., 2016).

SIZEit $=$ Logaritma Natural dari Total Asset perusahaan i pada periode $t$ 
Kebijakan utang diukur dengan membandingkan jumlah utang dengan total aset dalam satu periode yang dimiliki oleh perusahaan. Proksi kebijakan utang mengikuti (Faysal et al., 2020), dan (Appuhami, 2018).

$$
\text { DTAit }=\frac{\text { Total Utang perusahaan } \mathrm{i} \text { pada periode } \mathrm{t}}{\text { Total aset preusahaan i pada periode } \mathrm{t}}
$$

Pengujian hipotesis dalam penelitian ini menggunakan analisis regresi linier breganda untuk data panel. Penelitian ini menggunakan tiga model, model yang pertama merupakan model utama dengan menggunakan variabel dependen biaya modal, model yang kedua merupakan model tambahan dengan menggunakan variabel dependen biaya ekuitas, dan model yang ketiga merupakan model tambahan dnegan menggunakan variabel dependen biaya utang.

$$
\begin{aligned}
& \mathrm{COC}_{\text {it }}=\beta_{0}+\beta_{1} \mathrm{CSRI}_{\mathrm{it}}+\beta_{2} \mathrm{CGov}_{\mathrm{it}}+\beta_{3} \mathrm{LEV}_{\mathrm{it}}+\beta_{4} \mathrm{MTB}_{\mathrm{it}}+\beta_{5} \mathrm{ROA}_{\mathrm{it}}+\beta_{6} \mathrm{SIZE}_{\mathrm{it}}+\beta_{7} \mathrm{DTA}_{\mathrm{it}}+\varepsilon_{\mathrm{it}} \\
& \mathrm{COE}_{\mathrm{it}}=\beta_{0}+\beta_{1} \mathrm{CSRI}_{\mathrm{it}}+\beta_{2} \mathrm{CGOV}_{\mathrm{it}}+\beta_{3} \mathrm{LEV}_{\mathrm{it}}+\beta_{4} \mathrm{MTB}_{\mathrm{it}}+\beta_{5} \mathrm{ROA}_{\mathrm{it}}+\beta_{6} \mathrm{SIZE}_{\mathrm{it}}+\beta_{7} \mathrm{DTA}_{\mathrm{it}}+\varepsilon_{\mathrm{it}} \\
& \mathrm{COD}_{\text {it }}=\beta_{0}+\beta_{1} \mathrm{CSRI}_{\mathrm{it}}+\beta_{2} \mathrm{CGOV}_{\mathrm{it}}+\beta_{3} \mathrm{LEV}_{\mathrm{it}}+\beta_{4} \mathrm{MTB}_{\mathrm{it}}+\beta_{5} \mathrm{ROA}_{\mathrm{it}}+\beta_{6} \mathrm{SIZE}_{\mathrm{it}}+\beta_{7} \mathrm{DTA}_{\mathrm{it}}+\varepsilon_{\mathrm{it}} \text {. }
\end{aligned}
$$

Dimana:

$\mathrm{COC}_{\mathrm{it}}=$ biaya modal perusahaan $\mathrm{i}$, tahun $\mathrm{t}$

$\mathrm{COE}_{\mathrm{it}}=$ biaya ekuitas perusahaan $\mathrm{i}$, tahun $\mathrm{t}$

$\mathrm{COD}_{\text {it }}=$ biaya ekuitas perusahaan $\mathrm{i}$, tahun $\mathrm{t}$

$\mathrm{CSRI}_{\text {it }}=$ indeks tanggung jawab sosial perusahaan $\mathrm{i}$, tahun $\mathrm{t}$

$\mathrm{CGov}_{\mathrm{it}}=$ tata kelola perusahaan pada perusahaan $\mathrm{i}$, tahun $\mathrm{t}$

$\mathrm{SIZE}_{\text {it }}=$ ukuran perusahaan pada perusahaan $\mathrm{i}$, tahun $\mathrm{t}$

$\mathrm{LEV}_{\text {it }}=$ leverage pada perusahaan $\mathrm{i}$, tahun $\mathrm{t}$

$\mathrm{ROA}_{\mathrm{it}}=$ profitabilitas pada perusahaan $\mathrm{i}$, tahun $\mathrm{t}$

$\mathrm{MTB}_{\text {it }}=$ market-to-book pada perusahaan $\mathrm{i}$, tahun $\mathrm{t}$

$\mathrm{CS}$ it = struktur modal pada perusahaan $\mathrm{i}$, tahun $\mathrm{t}$

\section{HASIL ANALISIS DATA}

Tabel 2 menunjukkan hasil ringkasan statistik deskriptif untuk variabel-variabel dalam penelitian ini.

Tabel 2. Statistik Deskriptif

\begin{tabular}{lcccccccccc}
\hline & COC & COD & COE & CSRI & CG & LEV & MTB & ROA & SIZE & DTA \\
\hline Mean & 0.0318 & 0.0352 & 0.0264 & 0.4874 & 0.7089 & 0.8456 & 3.4499 & 0.0840 & 28.917 & 0.3960 \\
Median & 0.0207 & 0.0293 & 0.0030 & 0.3736 & 0.7200 & 0.5927 & 1.2920 & 0.0569 & 28.671 & 0.3721 \\
Max & 0.7011 & 0.1526 & 1.3231 & 2.4725 & 1.0000 & 4.1897 & 81.942 & 0.9210 & 33.494 & 0.8073 \\
Min & -0.2194 & 0.0000 & -0.2557 & 0.0879 & 0.2800 & 0.0833 & 0.0527 & 0.0000 & 25.795 & 0.0769 \\
Std. Dev. & 0.0953 & 0.0294 & 0.1467 & 0.3736 & 0.1963 & 0.6999 & 9.1304 & 0.0996 & 1.6134 & 0.1777 \\
\hline
\end{tabular}

Sumber: data diolah

Selanjutnya, pengujian dilakukan dengan menggunakan data panel, dengan fixed effect model (FEM) pada model 1 dan 2, random effect model pada model 3. Adapun ringkasan hasil uji hipotesis adalah sebagai berikut: 
Tabel 3. Hasil Pengujian Hipotesis

\begin{tabular}{|c|c|c|c|c|c|c|c|c|c|c|c|c|}
\hline \multirow[b]{2}{*}{ Var. } & \multicolumn{4}{|c|}{ Model 1 (COC) } & \multicolumn{3}{|c|}{ Model 2 (COD) } & \multicolumn{5}{|c|}{ Model 3 (COE) } \\
\hline & Coef. & t-Stats & Prob. & & Coef. & t-Stats & Prob. & & Coef. & t-Stats & Prob. & \\
\hline $\mathrm{C}$ & -0.835 & -2.499 & 0.013 & $* *$ & 0.111 & 2.226 & 0.0268 & $* *$ & -0.945 & -1.343 & 0.1806 & \\
\hline CSRI & -0.051 & -3.052 & 0.002 & $* * *$ & -0.0002 & -0.005 & 0.9960 & & -0.090 & -2.916 & 0.0040 & $* * *$ \\
\hline CG & 0.063 & 2.098 & 0.037 & ** & 0.001 & 0.170 & 0.8649 & & 0.169 & 3.491 & 0.0006 & $* * *$ \\
\hline LEV & -0.037 & -2.701 & 0.007 & $* * *$ & -0.022 & -3.422 & 0.0007 & $* * *$ & -0.047 & -1.441 & 0.1512 & \\
\hline MTB & 0.002 & 2.699 & 0.007 & $* * *$ & -0.0003 & -1.104 & 0.2704 & & 0.005 & 2.687 & 0.0078 & $* * *$ \\
\hline ROA & -0.073 & -0.802 & 0.423 & & -0.042 & -2.958 & 0.0034 & $* * *$ & -0.040 & -0.336 & 0.7370 & \\
\hline SIZE & 0.026 & 2.344 & 0.020 & ** & -0.0036 & -2.029 & 0.0435 & ** & 0.0278 & 1.158 & 0.2482 & \\
\hline CS & 0.289 & 3.985 & 0.000 & $* * *$ & 0.129 & 4.953 & 0.0000 & $* * *$ & 0.2934 & 2.362 & 0.0192 & ** \\
\hline $\mathrm{R}^{2}$ & & 0.563 & & & & 0.144 & & & & 0.080 & & \\
\hline Adj. $R^{2}$ & & 0.398 & & & & 0.121 & & & & 0.058 & & \\
\hline F-stat. & & 3.411 & & & & 6.092 & & & & 3.691 & & \\
\hline Prob(F-stat.) & & 0.000 & & & & .0000 & & & & 0.001 & & \\
\hline
\end{tabular}

Sumber: diolah

\section{DISKUSI}

Pengaruh Tanggung Jawab Sosial Terhadap Biaya Modal. Hasil pengujian menunjukkan bahwa tanggung jawab sosial berpengaruh negatif terhadap biaya modal. Hasil ini sejalan dengan pengujian tanggung jawab sosial terhadap biaya ekuitas. Namun, tanggung jawab sosial tidak berpengaruh terhadap biaya modal. Hasil pengujian tersebut menunjukkan bahwa implementasi tanggung jawab sosial perusahaan dapat menurunkan risiko perusahaan, namun hanya yang berkaitan dengan pemegang saham. Hasil pengujian ini sejalan dengan (Matthiesen dan Salzmann, 2016), (Weber, 2018), (Chen dan Zhang, 2021). Tanggung jawab perusahaan mampu mendorong manajer untuk melakukan tindakan-tindakan perusahaan yang lebih etis, sehingga perusahaan yang menerapakan tanggung jawab sosial dengan baik dapat mengurangi tindakan oportunistik manajer dalam menggunakan wewenangnya dalam menjalankan aktivitas perusahaan.

Ketika manajer menerapkan tanggung jawab sosial dalam operasi bisnisnya, manajer dapat memenuhi ekspektasi pemangku kepentingan. Manajer akan lebih bersikap etis dengan mendahulukan kepentingan pemangku kepentingan. Implementasi penerapan tanggung jawab sosial yang dilakukan oleh perusahaan mengakibatkan perusahaan lebih transparan dalam mengungkapkan informasi kepada publik. Implementasi ini memaksa perusahaan untuk meningkatkan kinerja perusahaan secara keseluruhan lebih efisien (Firmansyah et al., 2021), sehingga perusahaan mampu mengelola sumber daya secara optimal untuk menguntungkan perusahaan dan pemangku kepentingan (Adhima, 2012). Kondisi demikian memaksa perusahaan akan menjalankan kebijakan yang mendukung kepentingan pemangku kepentingan yaitu dengan menerapkan pemilihan sumber dana dengan lebih hati-hati. Manajer memahami penggunaan biaya modal yang lebih tinggi dapat mengakibatkan perusahaan dalam kondisi yang lebih beresiko. Walaupun implementasi tanggung jawab sosial perusahaan merupakan kegiatan yang sukarela dan filantropi, namun manajer menganggap bahwa aktivitas tersebut menciptakan keunggulan kompetitif yang dibutuhkan perusahaan. Oleh karena itu, tindakan ini dapat untuk menarik perhatian pelaku 
pasar khususnya investor (Firmansyah et al., 2021). Tindakan ini sejalan dengan tren penerapan isu keberlanjutan saat ini sehingga perusahaan mendapatkan manfaat ekonomi dalam bentuk penurunan risiko perusahaan.

Sejalan dengan hal tersebut, aktivitas penerapan tanggung jawab sosial perusahaan sejalan dengan memaksimalkan kekayaan pemegang saham (Cheung et al., 2013; Nuryaman, 2013). Aktivitas ini juga dianggap sebagai strategi yang dapat memberikan nilai tambah perusahaan dalam meraih pendapatan di masa sekarang dan mendatang. Aktivitas tanggung jawab sosial dapat memenuhi kebutuhan penyedia dana perusahaan khususnya investor terkait dengan etika bisnis yang dilakukan oleh perusahaan saat ini. Investor menganggap bahwa tindakan tanggung jawab sosial yang dijalankan oleh perusahaan merupakan aktivitas prioritas informasi dalam pengambilan keputusan investasi di pasar modal. Investor menganggap bahwa tanggung jawab sosial perusahaan terkait dengan dengan strategi-strategi keunggulan bersaing yang dilakukan oleh perusahaan pada umumnya. Namun, pandangan tersebut tidak berlaku bagi kreditor yang mungkin masih menganggap aktivitas tanggung jawab sosial berkorelasi dengan tingkat kemampuan perusahaan dalam memenuhi utangnya.

Pengaruh Tata Kelola Perusahaan Terhadap Biaya Modal. Hasil pengujian dalam penelitian ini menunjukkan bahwa tata kelola perusahaan berpengaruh positif terhadap biaya modal. Dalam pengujian tambahan menunjukkan bahwa tata kelola perusahaan berpengaruh positif terhadap biaya ekuitas, sedangkan tata kelola perusahaan tidak berpengaruh terhadap biaya utang. Temuan ini menunjukkan bahwa penerapan tata kelola perusahaan dapat mengakibatkan risiko yang ditanggung oleh perusahaan. Pelaksanaan tata kelola perusahaan di pasar modal hanya sebatas syarat administrasi yang diatur oleh Otoritas Pasar Modal di Indonesia (Saksessia dan Firmansyah, 2020). Dalam aturan tersebut masih belum diatur terkait dengan sanksi apabila perusahaan tidak menerapkan tata kelola perusahaan yang berkualitas. Dalam pelaksanaannya, perusahaan diperkenankan untuk mengungkapkan pernyataan comply or explain atas penerapan tata kelola perusahaan di dalam laporan tahunannya (Firmansyah et al., 2021). Selain itu, sampai dengan saat ini belum terdapat lembaga independen yang menilai kualitas penerapan tata kelola.

Walaupun secara rata-rata penerapan tata kelola di Indonesia tinggi, namun kondisi tersebut tidak menunjukkan kualitas tata kelola yang sesungguhnya. Kondisi ini bertentangan dengan pengurangan biaya agensi melalui praktik tata kelola yang lebih efektif (Mande et al., 2012). Penerapan tata kelola yang kurang berkualitas erat kaitannya dengan perlindungan investor yang rendah di Indenesia. Perlindungan investor dalam penerapan tata kelola tingkat perusahaan masih belum jelas (Hail dan Leuz, 2006). Pengaturan tata kelola perusahaan oleh perusahaan belum diatur secara rigid karena perusahaan boleh menyatakan comply or explain untuk menilai pelaksanaan pedoman tata kelola perusahaan. Pendekatan ini memberikan ruang bagi perusahaan untuk menafsirkan hasil pemahamannya masing-masing, sehingga tidak berfungsi dengan baik. Akibatnya, pengungkapan tata kelola perusahaan kurang memperhatikan kualitasnya (Saksessia dan Firmansyah, 2020), malah menimbulkan risiko bagi perusahaan. Hal ini terlihat dari betapa mudahnya perusahaan menyatakan telah memenuhi rekomendasi namun tidak ada bukti yang mendukung klaimnya (rata-rata hanya memenuhi $70,89 \%$ ). 
Selain itu, penerapan tata kelola perusahaan belum sesuai dengan harapan investor tentang praktik tata kelola perusahaan yang baik, sehingga informasi yang diungkapkan tidak dapat diandalkan untuk proses pengambilan keputusan oleh investor. Investor menganggap bahwa pengungkapan tata kelola yang dilakukan oleh perusahaan hanya klaim sepihak yang belum tentu sesuai dengan kualitasnya. Oleh karena itu, investor menuntut adanya tingkat pengembalian yang lebih tinggi atas perusahaan yang mengklaim secara sepihak atas tata kelola yang inggi. Hasil pengujian ini sejalan dengan (Breuer et al., 2018) dan (Feng et al., 2015) yang menyatakan bahwa pengaruh tata kelola terhadap pengurangan biaya terbatas pada negara-negara dengan perlindungan investor yang relatif lengkap, namun kondisi tersebut tidak terjadi di negara-negara dengan perlindungan investor yang rendah. Namun, bagi kreditor penerapan tata kelola perusahaan tidak berkorelasi dengan kemampuan perusahaan dalam memenuhi kewajiban atas pembayaran utang kepada kreditor.

\section{KESIMPULAN}

Implementasi tanggung jawab sosial perusahaan menurunkan biaya modal, sehingga perusahaan yang menerapkan tanggung jawab sosial perusahaan yang baik dapat menurunkan risiko akibat adanya pilihan pendanaan perusahaan. Sementara itu, implementasi tata kelola dapat meningkatkan biaya modal. Tindakan tata kelola yang hanya dijalankan untuk memenuhi syarat administrasi yang diatur oleh Otoritas Pasar Modal di Indonesia belum mampu menurunkan risiko perusahaan bahkan dapat meningkatkan risiko perusahaan.

Keterbatasan penelitian ini adalah penggunaan tata kelola perusahaan dan tanggung jawab sosial perusahaan menggunakan indeks pengungkapan yang diperoleh dari laporan tahunan maupun laporan keberlanjutan, sehingga unsur subyektifitas dalam penggunaan informasi tersebut masih tetap ada. Selain itu, penelitian ini menggunakan data mulai tahun 2016 karena indeks tanggung jawab sosial menggunakan GRI 2016 dan indeks tata kelola perusahaan menggunkaan SE OJK Nomor 32 tahun 2015, sehingga horizon waktu dalam penelitian ini yang relatif singkat. Penelitian selanjutnya dapat menggunakan horizon waktu yang lebih panjang dan proksi tanggung jawab sosial dan tata kelola perusahana yang berbeda sehingga penelitian selanjutnya dapat menghasilkan pengujian yang lebih baik dibandingkan dengan penelitian ini.

Penelitian ini mengindikasikan bahwa Otoritas Jasa Keuangan (OJK) selaku otoritas pengawas pasar modal perlu memperbaiki kualitas penerapan tata kelola dan tanggung jawab sosial perusahaan yang dilakukan oleh emiten di pasar modal Indonesia. Selain itu, perbaikan kebijakan tata kelola yang perlu dilakukan oleh OJK mendorong upaya perlindungan investor di pasar modal Indonesia. Selain itu, perbaikan kualitas implementasi tanggung jawab sosial dan tata kelola perusahaan dapat mendorong keyakinan perusahaan perbankan selaku kreditor yang lebih baik terhadap perusahaan lainnya. 


\section{DAFTAR PUSTAKA}

Aguilera, R. V., Rupp, D. E., Williams, C. A., and Ganapathi, J. (2007). Putting the S back in corporate social responsibility: A multilevel theory of social change in organizations. Academy of Management Review, 32(3), 836-863.

Ailawadi, K. L., Neslin, S. A., Luan, Y. J., and Taylor, G. A. (2014). Does retailer CSR enhance behavioral loyalty? A case for benefit segmentation. International Journal of Research in Marketing, 31(2), 156-167.

Albarrak, M.S., Elnahass, M., and Salama, A. (2019). The effect of carbon dissemination on cost of equity. Business Strategy and the Environment, 28(6), 1179-1198.

Albuquerque, R., Durnev, A., and Koskinen, Y. (2013). Corporate social responsibility and firm risk: Theory and empirical evidence. CEPR discussion papers.

Anggraeni, A. V., and Indarti, M. G. K. (2021). Pengaruh pengungkapan modal intelektual terhadap biaya modal ekuitas. Fair Value: Jurnal Ilmiah Akuntansi dan Keuangan, 4(1), 63-87.

Appuhami, R. (2018). The signalling role of audit committee characteristics and the cost of equity capital. Pacific Accounting Review, 30(3), 387-406.

Arimbi, R. A. D., dan Indarti, M. G. K. (2021). Pengaruh corporate governance terhadap biaya modal ekuitas: bukti empiris pada perusahaan manufaktur di Indonesia. Jurnal Ilmiah MEA (Manajemen, Ekonomi, dan Akuntansi), 5(2), 1794-1815.

Botosan, C., and Plumlee, M. (2002). A re-examination of disclosure level and the expected cost of equity capital. Journal of Accounting Research, 40(1), 21-40.

Botosan, C. A., Plumlee, M. A., and Wen, H. (2011). The relation between expected returns, realized returns, and firm risk characteristics. Contemporary Accounting Research, 28(4), 1085-1122.

Bouslah, K., Kryzanowski, L., and M'zali, B. (2013). The impact of the dimensions of social performance on firm risk. Journal of Banking \& Finance, 37(4), 1258e1273.

Brigham, E. F., dan Houston, J. F. (2018). Dasar-Dasar manajemen keuangan buku 1, terjemahan oleh Novietha Indra Sallama dan Febriany Kusumastuti, edisi 14. Jakarta: Salemba Empat.

Breuer, W., Muller, T., Rosenbach, D., and Salzmann, A. (2018). Corporate social responsibility, investor protection, and cost of equity: A crosscountry comparison. Journal of Banking \& Finance, 96, 34-55.

Brown, L., and Caylor, M. (2006). Corporate governance and firm valuation. Journal of Accounting and Public Policy, 25(4), 409-434.

Chang, Y., Hsieh, C. H., Wang, T. C., and Hsieh, T. Y. (2014). Corporate social responsibility, cost of equity and cost of bank loans (Vol. 6). International Review of Accounting, Banking \& Finance.

Chen, B., and Zhang, A. (2021). How does corporate social responsibility affect the cost of equity capital through operating risk? Borsa Istanbul Review. http://doi.org/10.1016/j.bir.2021.01.005.

Chen, K., Chen, Z., and Wei, K. (2009). Legal protection of investors, CG, and the cost of equity capital. Journal of Corporate Finance, 15(3), 273-289.

Chen, W., Chung, H., Hsu, T., and Wu, S. (2010). External financing needs, CG, and firm value. Corporate Governance: An International Review, 18(3), 234-249. 
Chollet, P., and Sandwidi, B. W. (2018). CSR Engagement And Financial Risk: A virtuous circle? International evidence. Global Finance Journal, 38, 65-81.

Core, E., Guay, W. R., and Rusticus, T.O. (2006). Does weak governance cause weak stock returns? An examination of firm operating performance and investors' expectations. The Journal of Finance, 61(2), 655-687.

Cox, P., and Wicks, P. G. (2011). Institutional interest in corporate responsibility: Portfolio evidence and ethical explanation. Journal of Business Ethics, 103(1), 143e165.

Crespi, R., and Martín-Oliver, A. (2015). Do family firms have better access to external finance during crises? Corporate Governance: An International Review, 23(3), 249265.

Cui, J., Jo, H., and Na, H. (2018). Does corporate social responsibility affect information asymmetry? Journal of Business Ethics, 148(3), 549-572.

Dittmar, A., and Mahrt-Smith, J. (2007). Corporate governance and the value of cash holdings. Journal of Financial Economics, 83(3), 599-634.

Drobetz, W., Schillhofer, A., and Zimmermann, H. (2004). Corporate governance and expected stock returns: evidence from Germany. European Financial Management, 10(2), 267-293.

Durnev, A., and Kim, E. (2005). To steal or not to steal: firm attributes, legal environment, and valuation. The Journal of Finance, 60(3), 1461-1493.

Eccles, R.G., Serafeim, G., and Krzus, M. P. (2011). Market interest in nonfinancial information. Journal of Applied Corporate Finance, 23(4), 113-127.

El Ghoul, S., Guedhami, O., Kwok, C. C., and Mishra, D. R. (2011). Does corporate social responsibility affect the cost of capital? Journal of Banking \& Finance, 35(9), 23882406.

Erbach, A. S. (2020). Pengungkapan intellectual capital dan nilai pasar ekuitas terhadap biaya modal ekuitas. Musamus Accounting Journal, 3(1), 30-39

Faysal, S., Salehi, M., and Moradi, M. (2020). The impact of ownership structure on the cost of equity in emerging markets. Management Research Review, 43(10), 1221 1239.

Febrininta, C. N., dan Siregar, S. V. (2014). Manajemen laba akrual, manajemen laba riil, dan biaya modal. Jurnal Akuntansi Multiparadigma, 5(3), 365-379.

Febriyanto, A. S., and Firmansyah, A. (2018). The effects of tax avoidance, accrual earnings management, real earnings management, and capital intensity on the cost of equity. Jurnal Dinamika Akuntansi, 10(1), 40-50.

Feng, Z. Y., Wang, M. L., and Huang, H. W. (2015). Equity financing and social responsibility: Further international evidence. The International Journal of Accounting, 50(3), 247-280.

Firmansyah, A., and Estutik, R. S. (2020). Environmental responsibility performance, corporate social responsibility disclosure, tax aggressiveness: does corporate governance have a role? Journal of Governance and Regulation, 9(4), 8-24.

Firmansyah, A., Fauzi, I., dan Yuniar, M. R. (2020). Biaya Utang dari Sudut Pandang Kebijakan Dividen, Volatilitas Laba, dan Kualitas Akrual. Akurasi: Studi Akuntansi dan Keuangan, 3 (2), 109-129. 
Firmansyah, A., dan Suhanda, N. H. (2021). Bagaimana peran tata kelola perusahaan dalam hubungan antara manajemen laba dan risiko idiosinkratik di Indonesia? Jurnal Ekonomi, 26(2), 229-249.

Firmansyah, A., Febrian, W., Jadi, P. H., Husna, M. C., dan Putri, M A. (2021). Respon investor atas tanggung jawab sosial tata kelola perusahaan di Indonesia: perspektif resource based view. E-Jurnal Akuntansi, 31(8), 1918-1935.

Flammer, C., and Luo, J. (2017). Corporate social responsibility as an employee governance tool: Evidence from a quasi-experiment. Strategic Management Journal, 38(2), 163183.

Galbreath, J., and Shum, P. (2012). Do customer satisfaction and reputation mediate the CSReFP link? Evidence from Australia. Australian Journal of Management, 37(2), 211-229.

Garay, U., and Gonzales, M. (2008). Corporate governance and firm value: the case of Venezuela. Corporate Governance: An International Review, 16(3), 194-209.

Girerd-Potin, I., Jimenez-Garces, S., and Louvet, P. (2014). Which dimensions of social responsibility concern financial investors? Journal of Business Ethics, 121(4), 559576.

Hail, L., and Leuz, C. (2006). International differences in the cost of equity capital: do legal institutions and securities regulation matter? Journal of Accounting Research, 44(3), 485-531.

Hidayah, N., dan Firmansyah, A. (2020). Implementasi likuidasi korporasi di Indonesia: kajian akuntansi dan yuridis. Jurnal Ilmiah Wahana Akuntansi, 15(2), 184-196.

Hill, C. W. L., and Jones, T.M. (1992). Stakeholder-agency theory. Journal of Management Studies, 29(2), 131-154.

Hung, M., and Trezevant, R. (2003). Insider trading and CG structure: evidence from Southeast Asia. Working paper, Marshall School of Business University of Southern California.

Hutagaol, J. A., dan Lubis, R. H. (2021). Pengaruh pengungkapan modal intelektual terhadap biaya ekuitas pada perusahaan otomotif yang terdaftar di BEI. Jurnal Multidisiplin Madani(MUDIMA), 1(1), 41-50.

Ida, I. (2010). Pemilihan sumber pendanaan perusahaan berdasarkan hipotesis pecking order. Jurnal Akuntansi, 2(1), 93-100.

Jensen, M. C., and Meckling, W. H. (1976). Theory of the firm: managerial behavior, agency costs and ownership structure. Journal of Financial Economics, 3(4), 305-360.

Harjoto, M. A., and Jo, H. (2015). Legal vs. normative CSR: Differential impact on analyst dispersion, stock return volatility, cost of capital, and firm value. Journal of Business Ethics, 128(1), 1-20.

Johnson, S., Boone, P., Breach, A., and Friedman, E. (2000). Corporate governance in the Asian financial Crisis. Journal of Financial Economics, 58 Nos 1/2, 141-186.

Khanchel El Mehdi, I. (2007). Empirical evidence on CG and corporate performance in Tunisia. Corporate Governance: An International Review, 15(6), 1429-1441.

Kovermann, J. H. (2018). Tax avoidance, tax risk and the cost of debt in a bank-dominated economy. Managerial Auditing Journal, 33(8/9), 683-699.

La Porta, R., Lopez-de-Silanes, F., Shleifer, A., and Vishny, R. (2000). Investor protection and CG. Journal of Financial Economics, 58(Nos 1/2), 3-27. 
Le, H. T. T., Vo, X. V., and Vo, T. T. (2021). Accruals quality and the cost of debt: Evidence from Vietnam. International Review of Financial Analysis, 76, 101726.

Lei, A. C. H., and Song, F. M. (2005). Corporate governance, family ownership and firm valuations in emerging markets: evidence from Hong Kong Panel data. Working Paper, SSRN.

Lombardo, D., and Pagano, M. (2002). Law and equity markets: a simple model. Working Paper, University of Salerno.

Luo, X., and Bhattacharya, C. B. (2009). The debate over doing good: corporate social performance, strategic marketing levers, and firm-idiosyncratic risk. Journal of Marketing, 73(6), 198-213.

Masulis, R.W., Wang, C., and Xie, F. (2007). Corporate governance and acquirer returns. Journal of Finance, 62(4), 1851-1889.

Matthiesen, M-L, and Salzmann, A. J. (2016). Corporate social responsibility and firms' cost of equity: how does culture matter? Cross Cultural \& Strategic Management, 24(1), 105-124.

Morey, M., Gottesman, A., Baker, E., and Godridge, B. (2009). Does better CG result in higher valuations in emerging markets? Another examination using a new data set. Journal of Banking and Finance, 33(2), 254-262.

Parendra, A., Firmansyah, A., dan Prakosa, D. K. (2020). Ukuran perusahaan, leverage, risiko saham di perusahaan perbankan. Dinamika Akuntansi, Keuangan dan Perbankan, 9(2), 119-132.

Raimo, N., de Nuccio, E., Giakoumelou, A., Petruzzella, F., and Vitolla, F. (2020). Nonfinancial information and cost of equity capital: an empirical analysis in the food and beverage industry. British Food Journal, 123(1), 49-65.

Rohman, M. S., dan Ismanto, H. (2020). Determinan biaya modal ekuitas: studi empiris pada perusahaan properti, real estate dan kontruksi bangunan. Journal of Applied Business and Economics (JABE), 7(2), 194-208.

Salman, I., Firmansyah, A., dan Widyaningrum, M. R. (2020). Peran leverage sebagai pemoderasi: revaluasi aset tetap, kebijakan dividen, nilai perusahaan. Jurnal Magister Akuntansi Trisakti, 7(2), 171-190.

Schauten, M. B. J., Van Dijk, D., and Van der Waal, J. (2008). Corporate governance and the value of excess cash holdings of large European firms. European Financial Management, 18(5), 991-1016.

Shleifer, A., and Vishny, R. (1997). A survey of corporate governance. Journal of Finance, $52,737-83$.

Tamimi, N., and Sebastianelli, R. (2017). Transparency among S\&P 500 companies: an analysis of ESG disclosure scores. Management Decision, 55(8), 1660-1680.

Teti, E., Dell'Acqua, A., Etro, L. and Resmini, F. (2016). Corporate governance and cost of equity: empirical evidence from Latin American companies. Corporate Governance, 16(5), 831-848. https://doi.org/10.1108/CG-02-2016-0028.

Vermander, B. (2014). Corporate social responsibility in China: A vision, an assessment and a blueprint. World Scientific.

Weber, J. L. (2018). Corporate social responsibility disclosure level, external assurance and cost of equity capital. Journal of Financial Reporting and Accounting, 16(4), 694724. 
Widyowati, D. D. (2020). Pengaruh manajemen laba, asimetri informasi, dan pengungkapan sukarela terhadap biaya modal ekuitas. Paradigma, 17(2), 69-87.

Xu, S., Liu, D., and Huang, J. (2015). Corporate social responsibility, the cost of equity capital and ownership structure: An analysis of Chinese listed firms. Australian Journal of Management, 40(2), 245-276.

Yawar, S. A., and Seuring, S. (2017). Management of social issues in supply chains: A literature review exploring social issues, actions and performance outcomes. Journal of Business Ethics, 141(3), 621-643.

Zhang, M., Ma, L., Su, J., and Zhang, W. (2014). Do suppliers applaud corporate social performance? Journal of Business Ethics, 121(4), 543-557. 